\title{
Posthumanism, Animism, and Sérgio Medeiros's Pluriverse Poetics
}

\author{
MALCOLM MCNEE \\ Smith College
}

\begin{abstract}
The works of Sérgio Medeiros are populated by a multitude of beings of diverse and often shifting orders and species. Drawing upon intersecting conceptual orientations of animal and multispecies studies, posthumanism, and ecocriticism, I survey a range of interspecies encounters and worldings in Medeiros's writing, especially his collection of poems, $O$ choro da aranha, etc. (2013). As Medeiros pointedly draws inspiration from diverse aesthetic and philosophical traditions-from Amerindian cosmogonies and verbal arts to Japanese Zen poetry and various strains of modernist avantgardism-I trace here as a unifying feature his engagement with animist imaginings and a post- or anti-anthropocentric unsettling of human/non-human binaries and boundaries.
\end{abstract}

Keywords: Brazilian poetry; indigeneity; literature and the environment; multispecies studies; Eduardo Viveiros de Castro

The non-human other has of course been a feature of and inspiration for human metaphysical speculation, ethical/ontological inquiry, and aesthetic practice since time immemorial, and there are certainly clear continuities and modulations to be traced between the present, in this regard, and periods and practices of any variety of remoteness. There is now, however, a distinctly intensifying and palpable sense of urgency to the interrogation and exploration of real and conceptual/ontological relations between human and other-than- 
human entities and worlds. The manifestations of this present urgency may feature more continuities than ruptures with deeply ingrained habits and structures of feeling, thinking, and representing the human/other-than-human duality. Even then, they seem to demand renewed or altered attention and evoke newly vital auras of meaning given the present context, one indelibly marked by the pall of unfolding, catastrophic, anthropogenic environmental change on a planetary scale. How do we consider or reconsider the human in its relationship with non-human others and with more-than-human environments and worlds at a moment of truly geological rupture? How might art and literature respond to, reveal, or be read in dialogue with an epochal shift that somehow parallels yet ultimately dwarfs - if not renders trivial — established senses and languages of periodization? Rather than considering transitions from antiquity through preand postmodernity, are we not now, to some growing degree, compelled to think and locate the text, our reading, and their meanings within the transition from the Holocene to the Anthropocene or, perhaps somewhat more finely scaled, between the Anthropocene and, as it has rather ominously been characterized, the current period of its Great Acceleration? ${ }^{1}$

In response to or alongside these conditions and questions, we have seen the emergence and dynamic unfolding of a number of new and overlapping transdisciplinary fields and critical/conceptual apparatuses and methodologies, including Animal Studies, Posthumanism, Multispecies Studies, and, ever more expansively configured, Ecocriticism and Environmental Humanities. ${ }^{2}$ These emergent fields also include decolonial inflections, as they intersect with Indigenous cosmopolitics and the reinvigorated practice of theorizing with and

\footnotetext{
${ }^{1}$ Anthropocene has become firmly established as the emergent term for the ecological present, though there are other terms that have been proposed to signal both the end of the Holocene and the conceptual, strategic, political shortcomings or blind-spots associated with Anthropocene as a term. Alternatives include the Capitolocene and the Plantationocene, which point to capitalism or the slave plantation as the dominant engines of ecological destruction. In a more aspirational spirit, the Sustainocene or Donna Harroway's Cthulucene call upon us to make kinship and morethan-human alliances with diverse earthwide forces and entities. For a quick review of an expansive list of proposed “-cenes," see Mentz. For an excellent consideration of Brazil's historical place in what he calls a "common but differentiated Anthropocene," as well as a proposed distinction between a First Anthropocene and its current Great Acceleration, see Pádua. ${ }^{2}$ For introductions to the intersections between these emergent approaches and literary studies, see Gennaro; Ortiz-Robles.
} 
from non-dualistic Indigenous epistemologies and ontologies of nature and personhood. Engaging with these unfolding critical discussions, this article offers an eco-oriented reading of work by contemporary Brazilian poet, essayist, and translator, Sérgio Medeiros, surveying in it a range of interspecies encounters and worldings. ${ }^{3}$ As Medeiros's writing pointedly asserts kinship with radically diverse assemblages of artistic and philosophical traditionsfrom Amerindian cosmogonies and verbal arts, to Japanese Zen poetry, to various strains and figures of modernist avant-gardism - the reading here traces as a unifying feature animist imaginings and post- or anti-anthropocentric contestations of the dualist ontologies of human/non-human that undergird the modern, Cartesian construction of human subjectivity.

Medeiros was born in 1959 in Bela Vista, Mato Grosso do Sul (then Mato Grosso, before its separation into two states), and he now resides in Florianópolis, where he is a professor of literature at the Universidade Federal de Santa Catarina. Like the late matogrossense poet Manoel de Barros, with whom he shares a number of thematic and conceptual affinities, Medeiros grew up in a cultural, linguistic, and epistemological border region, where Portuguese and Spanish mingled with each other, along with Guarani and other Indigenous languages. Medeiros has declared a regional basis for the animistic and trans-species optics that he shares with Barros. Unlike Barros, however, whose relationship with Indigenous languages and verbal arts is not so clearly or consistently signaled as a sustained object of reflection or intertextual engagement, Medeiros has built his literary corpus upon or alongside a substantial practice of ethnolinguistic scholarship and translation of Indigenous texts. ${ }^{4}$ His doctoral dissertation explores the mythology of the Jê linguistic

\footnotetext{
${ }^{3}$ For Haraway, this term both signals ways of world-making and unmaking in the interactions and entanglements of different species, materialities, and technologies, and our conceptualizations, perceptions, and speculative imaginings of those existing and possible entanglements, the imagined and lived situatedness of the human self in interspecies networks or more-than-human worlds.

${ }^{4}$ Engagement with Indigeneity, thematically and intertextually, in Manoel Barros's poetry is a question that merits further research and reflection. In researching the critical bibliography on his work in support of my own readings of it as ecopoetry (The Environmental Imaginary), I found no studies that substantially address what seems a potentially rich vein of meaning and interpretation. In "Turns to the Native," I consider Medeiros among a group of poets, including
} 
group, which includes the Kayapó and Xavante peoples, among others, and he has published translations and commentaries on a variety of Amerindian mythopoetic traditions, including a volume of Amazonian myths (Macunaíma e Jarapuri), and the first translation into Portuguese of the Popol Vuh. As Medeiros has stated:

A linguagem indígena sempre me interessou, e hoje ainda mais, porque ela propicia o encontro sobrenatural com o Outro. Nela, o outro radical, ou o absolutamente outro, não paralisa, mas abre um mundo novo, o mundo dos contatos e das mesclas impossíveis. [...] Em todos os mitos ameríndios a fronteira entre o humano e o não-humano é questionada ou reinventada de forma radical, surpreendente. (Leão)

The relationship between studied and creative engagement with Indigeneity is expressly evident in Medeiros's work, and it gives ballast to the playfully chaotic animism and multispecies tableaus of his poetry and fiction.

At the same time, as noted above, Medeiros freely remixes and imagines affinities between these Indigenous influences and inspirations with an eclectic, transcultural panoply of figures and forms, including nonsense poetry, classical haiku, mid-century avant-garde music and performance art, and contemporary philosophy and anthropological theory, to name just a few of the realms of expression and inquiry signaled in his creative work. This includes, to date, just over a dozen books that range in and blend form and genre, including verse and prose poetry, short story and novella, dramatic and satirical dialogues and plays. This is work that revels in defying or unsettling generic distinctions-in a way mirroring both the blurred boundaries between species and orders of being in his texts and also the unsettling of literary classification posed by Indigenous literatures and verbal arts. ${ }^{5}$ Beyond the genre disruption and play and animist affinities, the intertextualities and constantly shifting, multicultural and multi-species perspectives in his work can be read as linking and enacting through the realm of experimental poetics key concepts such as

Josely Vianna Baptista and André Vallias, for whom sustained engagement with Indigeneity and Indigenous verbal arts is a clearly signaled and sustained dimension of their work.

${ }^{5}$ See, on this latter question, Ajens, "Indigenous Liter-ature," "On Amerindian Language." 
"multinaturalism" and the "pluriverse," concepts that bridge and animate posthumanism and decolonial theory and cosmopolitics. Multinaturalism is the concept drawn by Brazilian anthropologist Eduardo Viveiros de Castro from animistic Amerindian epistemes out of which he theorizes a counterpoint to Western, dualist understandings of nature/culture, human/non-human, etc. And, as described by posthumanist geographer, Juanita Sundberg: "Scholars identified with the modernity/coloniality framework offer the concept of the pluriverse as a strategy for moving away from the universalizing and colonizing notion of the universe. [...] The pluriverse entails imagining the performative enactment of multiple, distinct ontologies or worlds" (38). Eduardo Viveiros de Castro's multinaturalism, drawn from his analysis of a diverse corpus of Native cosmologies and narratives in the Americas, conceptually signals the multiplicity of worlds or natures figured by the distinct but relational points of view and subjectivities of different species-beings, all of which share a common underlying or original humanity or personhood. That is, there is a unified world of shared humanity in which there are multiple worlds or natures figured by the different physical forms the observant subject or person takes. ${ }^{6}$ Meanwhile, the pluriverse much more broadly considers the historical and ongoing colonial violence of reducing the world to one epistemic system. Though Medeiros's work is not immediately legible as politically engaged with concrete environmental conservation and justice issues, or with Indigenous human rights and territorial struggles, this reading proposes that it be understood as reflecting on and creatively enacting non-dualist, posthumanist, anti-anthropocentric ontologies and a decolonization of poetry, aesthetic practice, and the environmental imaginary in Brazil, and beyond.

This feature is clearly manifested in his 2009 collection, $O$ sexo vegetal, which was translated and published in a bilingual English and Portuguese edition in 2010 as Vegetal Sex. In fact, Medeiros includes among his epigraphs for this book a dictum-like statement from Viveiros de Castro's seminal $A$ Inconstância da Alma Selvagem, "To know is to personify, to take on the point of view of that which must be known" (8). Thematically focused on realms and episodes of vegetal and human coexistence and encounter, $O$ sexo vegetal

\footnotetext{
${ }^{6}$ For a consideration of the affinities and intertextualities between Medeiros and Viveiros de Castro, see McNee, The Environmental Imaginary and Cisneros.
} 
begins with a preface and manifesto in a clipped, deadpan style that evokes the spirit and form of Oswald de Andrade's "Manifesto Pau-Brasil" and "Manifesto Antropófago." Titled "O Sexo Vegetal é uma Cosmogonia," Medeiros's manifesto matter-of-factly grounds the collection in animist epistemologies that disperse divinity and personhood across a broad spectrum of beings, and it proclaims the erotics of all cosmogonies, with their emphasis on origins, births, and contacts between beings that constantly bring the world into existence. The manifesto is footnoted with a general reference to "os mitos ameríndios" as source of animist inspiration, as well as more specific references to works by Claude Lévi-Strauss and Michel Serres, the latter author of some of the foundational works of posthumanist thought. The collection that follows is largely composed of an interspersing of two prose-poem forms. The poems of the first form, each titled "decór," are akin to miniature landscapes and, like haikus, they use a spare and condensed yet lyrically evocative and precisely descriptive language to present dynamic ambiences of varying scale, through an inventory of their compositional elements or entities. These are all outdoor scenes that involve some vegetal presence in its proximity or entanglement with other entities - mountains, clouds, the wind, elements of a built environment, animals, and, in a few cases, humans. Their denomination as decór is subtly ironic as they forcefully convey a sense of active, willful protagonism of the elements they contain. These are pulsating, intensely alive settings that evoke moods ranging from the sensual to the threatening to the merely bizarre, and the active presence of what is normally regarded or disregarded as background is made apprehensible with the relative suspension of anthropocentric presence and drama. Interspersed with these are untitled prose-poems of varying length that enact or relate some form of human/vegetal encounter or entanglement. Variations on this theme in these poems range from dramatic to enigmatic to quietly minimalist, and they include forms of contact recognizable as erotic, extending notions of intimacy into moments and realms of human/vegetal coexistence. $^{7}$

\footnotetext{
${ }^{7}$ For a closer reading of $O$ sexo vegetal alongside Medeiros's earlier, much less overtly animist collection of poems (Alongamento), see McNee, The Environmental Imaginary. In Alongamento, the "decór" form is given the name "descritos," which Myriam Ávila describes as a deictic or demonstrative form, emphasizing that which is pointed out rather than the one who is pointing.
} 
In a series of more recent works, published in relatively quick succession, Medeiros has continued to activate an animist gaze through a variety of blended forms and intertextualities. His 2012 collection, Totens, includes two loosely narrative texts, "Enrique Flor" and "O Eletoesques," each combining verse and prose poems. Medeiros ascribes to these narratives a totem. In the case of the first, it is the tropical forest. In the second, it is the "bafo de verão" that Medeiros describes as a personified, metamorphic entity. According to legend in the Brazil/Paraguay border region; "qualquer pessoa, ao sair de casa sem chapéu ou sombrinho, pode transformar-se em eletoesqu (um bafo de verão), se o sol estiver muito forte e a rua deserta" (181). "Enrique Flor" conjures a protagonist out of a minor character/alter-ego in James Joyce's Ulysses, relating the adventures and ecstatic quest of a Portuguese composer and organist who seeks in Brazil's exuberant flora and landscapes a harmonic, sonic, and erotic fusion of art, self, and nature.

O desencontro dos canibais (2013) is composed of three cycles of loosely threaded vignettes, all variations on a theme in which a protagonist, a solitary canibalzinho or canibalzinhais perplexed by a feeling of solitude among the multitudes of other entities of their surroundings. He or she witnesses or engages in a series of anthropophagous gestures and rituals, in which beings devour one another or themselves in oneiric displays of recognition and remaking of self and other. In a preface to the book, anthropologist Pedro Cesarino finds a resignification of ritual anthropophagy that transcends the typically intercultural, identitarian symbolic framing it was given in Brazil's modernist circles, locating it within a much broader context of interspecies relations and environmental entanglement:

Nestas páginas, o canibalismo será reinventado e investido de uma potência criadora, capaz de gerar alteridades e estados insuspeitos. O livro-cidade-floresta é povoado por árvores que se comem entre si, por gaivotas e urubus que quase desaparecem por não resistirem ao impulso de autodevoração, por personagens que atravessam estados animais e vegetais

With the deictic form, the things pointed out are always directly before the gaze and the moment is the present, without the filter of memory. 
entrecruzados [...]. Apresenta-se um mundo em que a própria Terra carece de solidez e parece se liquefazer, como se ainda não tivesse fronteiras ou contornos definidos.

O fim de tarde de uma alma com fome (2015) is a dramatic poem in three acts, each one a variation on single story. Any of these variations, Medeiros proposes, might be substituted by the reader with another text - the above mentioned Popol Vuh or Makunaíma e Jurupari, or Heberto Helder's Poemas Ameríndios, or even by a "filme sobre animais, ou índios, ou soldados, ou sobre estes três assuntos, que estiver passando na televisão" (11). The poem largely takes the form of dialogue between two entities, a soldier and a tapir, the latter also identified as an old woman and a cannibal soul. As Lúcia Sá proposes in the book's preface, it develops in intertextual dialogue with a northern Amazonian, Pemon story about the origins of two plant-derived poisons used for fishing: "Como no conto pemon, o diálogo entre esses seres de espécies distintas é marcado por diferenças perspectivistas: o que para ela é uma cobra, para ele é um fogão; o que para ela são pérolas, para ele são carrapatos, e assim por diante."

In the space remaining, I examine Medeiros's $O$ choro da aranha etc. (2013), pausing along the way to consider its resonances with posthumanist concepts and thinking. This collection of poems gestures toward a constellation of terms, ideas, and representational approaches - such as entities-inassemblages, multispecies relationships and intersubjectivities, multiepistemic literacies, the pluriverse, and relational ontologies - meant to unsettle dualistic understandings of the human. Medeiro's poems here manifest clear resistance to human exceptionalism and a refusal, in the words of Sundberg "to treat the human as: 1) an ontological given, the privileged if not the only actor of consequence and; 2) disembodied and autonomous, separate from the world of nature and animality" (34). This book again positions Indigenous cosmovisions as well as a pantheon of avant-garde or experimentalist writers, musicians, and artists as inspiration and sources of creative, animist and anti-anthropocentric thinking, expression, and affinity. As such, it bridges what Sundberg critically identifies as the historic separation between posthumanist theory and Indigenous epistemes. 
O choro da aranha etc. is composed of eight distinctly titled sections or pieces - some comprising a cycle of poems and others just a single poem - that loosely overlap or are linked in formal and/or thematic features. Without any single one of these tightly binding all of the pieces together, they are still firmly coherent in their entanglings of relational difference. The collection directly invokes the spirits of lost writers, artists, shamans, and companion animals. It builds upon the decór or descrito form of his other collections, with short-form, ambient poems in which multispecies assemblages are attentively witnessed in their intense vitality. And it locates the human (the poetic self and others) in a variety of forms of engagement and coexistence, systematic or casual, with animal others. The first section, "O choro da aranha ou saudades de São Paulo," is the longest, including roughly forty short, ambient poems. This series is interrupted by a longer, multi-part poem described as recited during a visitation by the ghost of the concrete poet, Haroldo de Campos, accompanied by a "coiote misterioso que lhe estende a pata" (28). In this cycle, Medeiros conjures a delimited sense of place — a backyard garden and its immediately adjacent, visible surroundings - drawn through the protagonism or perspectives of its non-human inhabitants, most often orchids, spiders, and a dog called "Big Ah", but also birds, worms, fallen leaves, a lizard, trees, and insects. The house and its garden are repeatedly identified as "selvagem," and there is a meticulously crafted sense of wild natures cultivated through these poems, with minimal human presence and few references to the location of this environment within a larger urban context. There are just a few glancing views out onto a street with its passing cars and garbage collectors, and a poem titled, "A sufocante cidade ao redor," that contemplates a beam being raised for the construction of a building. towering over the "casa selvagem." Through an ontologically flattening gaze, these poems convert mostly abject, minor beings into coexistant and equally willful agents, each displaying a distinct but overlapping sensory awareness of this delimited world.

Signaling and unsettling counterpoints between wildness and domesticity, the human and the other-than-human, Big Ah, the dog, has particularly pronounced protagonism in this series. Poems often focus on his perception of his surroundings, which he sees, in kinship with the poet, as wild, mysterious, and surprising. One poem speculates about Big Ah dreaming, or perhaps suffering a nightmare, about a coyote, and in an interruption of the continuity of 
the backyard or garden setting, a series of three short poems, "Coiote," "Little John e o Big Ah," and "Público," contemplates the experience of the coyote, named Little John, used in Joseph Beuys's iconic 1974 performance, "I Like America and America Likes Me." The second of these three poems revisits the gallery space shared by Little John and Beuys for three days where, after the end of the performance and the artist's departure, the coyote is left alone, nervously trotting in circles. Medeiros recovers through his poetic interrogation a sense of Little John's willful agency from within the realm of symbolic or conceptual abstraction in which the work had captured him. Then, muddling senses of domesticity and wildness, the poem returns to an image of Big Ah, alone at the gate of his "casa selvagem" awaiting the arrival of his people. In the third poem of the series, "Público," Medeiros returns to the performance of cohabitation itself and offers a reassessment of sources and perception of danger: "Havia na galeria dois montes de feltro / Num deles Little John se deitava quando queria / Não de costas para o público / Pois o perigo era a curiosidade em pé atrás da barreira / Beuys fumava deitado num monte de palha num canto da sala" (50). This recognition and contemplation of the animal other's gaze and perspective illuminates the distinct forms and limitations of knowing and capacity for knowing the other-than-human animal and reminds us of the possible and necessary role of the poetic imagination in the task of thinking about, with, and through animals, our own animal alterity and multispecies relationships and entanglements. Maria Esther Maciel revisits one of the foundational moments in the articulation of Posthumanism and Animal Studies as emergent critical fields, Jacques Derrida's 1997 seminar, "L'animal que donc je suis." She notes the privileged position that it attributed to poetry as a form thinking about and with the animal:

Derrida aponta duas grandes 'situações de saber' sobre os animais: a que reduz o animal a uma coisa, 'uma coisa vista mas que não vê,' e a que se sustenta na troca de olhares com ele. A primeira assentada na cisão abissal entre humanidade $\mathrm{e}$ animalidade, justificada pela ideia de logos. A segunda, tomada como uma recusa do conhecimento exclusivamente racional, adviria do desejo de apreender o outro também pelos sentidos e pelo coração. A partir dessas duas possibilidades humanas de 
conhecer os viventes não humanos, Derrida formula uma proposição: 'Pois o pensamento do animal, se pensamento houver, cabe à poesia, eis aí uma tese, e é disso que a filosofia, por essência, teve de se privar. É a diferença entre um saber filosófico e um pensamento poético.' (89)

Medeiros builds upon the poetic rendering of exchanged gazes and perspectives in human/other-than-human relationships and relationality in another quite lengthy section of the collection. In "Canto de caça bororo," following a threepage commentary and introduction, Medeiros presents his translation from Bororo into Portuguese of a song for hunting tapirs. The song is structured around a shifting back and forth between the perspective of the hunters, as they look upon their prey, and that of the tapir, as it gazes back upon them. The voice of the hunters praises the beauty of the tapir: "Que lindas as antas! / Que lindas patas! / Que lindos quartos!" (86). It also acknowledges among the tapirs differentiated social subjectivities:

Viva! Olá, antas chegamos

Viva! Olá, grande anta, chegamos.

Viva! Olá, dona anta, chegamos.

Viva! Olá seu anta, chegamos.

Viva! Olá, cria que mama, chegamos. (86)

A shared attribution of personhood is also manifest in the response of the tapirs, voicing their gaze upon and recognition of the beauty of the hunters and their adornments, and in this exchange of perspectives, the Bororo see themselves but also other species-beings and elements of the shared environment through the eyes of the tapir other. The inclusion of the song in this collection, along with a substantial commentary on the history and ethnology of the Bororo and his approach to his translation, in which he hopes to recover or recreate certain aesthetic and sonic qualities, is another instance of generic disruption as a feature of Medeiros's work at large, in this case directly incorporating into a book of poetry a work of ethnopoetics. It also further manifests the anthropomorphism that runs through Medeiros's work at large, giving it value as a source of poetic renovation as well as a way of knowing. 
Medeiros incorporates into $O$ choro da aranha etc. a strong presence of Indigeneity and intertextuality with Indigenous mythopoetics without reifying them or asserting an absolutist or purist sense of Indigenous epistemic or aesthetic alterity. As in his other works, Medeiros weaves in this collection a network of affinities and symbolic kinships among figures and artifacts representing diverse cultural, regional, temporal, or aesthetic locations or positionalities. In a poem immediately following the hunting song, Medeiros imagines a Bororo funeral for the Cuban-American artist, Ana Mendieta, best known for her "earth-body" sculptures. Mendieta, and a number of her specifically named series of works, also feature in the preface, as reference and inspiration for the Medeiros's book. In another single-poem section, Medeiros conjures the spirit of Jerônimo Tsawé, a respected Xavante shaman and storyteller, sighted on a sidewalk in São Paulo, leaning on a staff, "como num totem," calmly staring down the intense traffic. ${ }^{8}$ Elsewhere we find passing references to or apparitions of the Austrian philosopher and novelist Robert Musil, the Japanese poet Bashô, the American minimalist artist Carl Andre, and the Belgian writer Henri Michaux. In "Animal Spirits," a poem that scans a tangle of species-beings (insect, lizard, gull, bird, boy) sharing, in states of willful action and observation, Medeiros even evokes John Maynard Keynes, who speaks of "animal spirits" as a way to account for spirit or instinct as a driver of human thought and action. The entanglement of beings here figures poetry as a site for bringing into being pluriversal worlds, for fostering play, exchange, learning, and dialog between distinct but potentially overlapping and mutually comprehensible perspectives, epistemes and aesthetic/creative visions.

Before concluding, it is worth discussing one more relatively lengthy section of $O$ choro da aranha etc., as a final example of the tireless formal inventiveness and variability through which Medeiros presents or activates a relatively unified realm of animist and multispecies imagery and meaning. In another English-titled poem, "Writing for the Second Time through Memórias Póstumas de Brás Cubas," Medeiros presents a series of fragments taken from numerically identified chapters of Machado de Assis's novel and follows them

\footnotetext{
8 Medeiros ("O dono") explains that he discovered Tsawé through the work of Salesian missionaries who were dedicated to collecting and publishing narratives from the neighboring Xavante people and who published two volumes of Tsawé's stories in the 1970s. Medeiros visited Tsawé 1987 as a graduate student embarking on his own study of Xavante narratives.
} 
with further examples of his ambient prose-poems, identifying in densely descriptive and precise language elements of the surrounding environmentlight, sound, vegetation, insects, etc. The locating of the reading in the world and among these dynamic entanglements of beings segues into, in the final selection of fragments, examples of ambient writing and attentiveness in Machado's novel itself, gesturing toward an oblique, ecocritically minded reading of a literary classic:

\section{Capítulo 3}

\section{[...] acabemos de uma vez [...]}

A trepadeira parcialmente iluminada parece barro atirado na copa das árvores por um veículo que longe na noite atola-se mais e mais rolando as rodas. (66)

\section{Capítulo 15}

$$
[\ldots] \text { cego }[\ldots]
$$

Uma pequena luz branca o único estilhaço (66)

\section{Capítulo 19}

$$
\begin{aligned}
& {[\ldots] \text { doido }[\ldots]} \\
& {[\ldots]-[\ldots],--[\ldots]} \\
& {[\ldots] \text { um }[\ldots]}
\end{aligned}
$$

O mato está parado como um só imenso tronco onde um inseto ou pássaro ronca como uma torneira que secou. (68)

\section{Capítulo 103}

[...] uma mosca arrastava uma [...] (71)

Capítulos 103/160

$$
\begin{aligned}
& {[\ldots] \text { mosca! }[\ldots] \text { formiga! }} \\
& {[\ldots] \text { mistério }[\ldots](72)}
\end{aligned}
$$

This form here, incorporating within it the deictic "decór" or "descrito" form described above, draws fragments of the referenced text and an attentively perceived assemblage of beings surrounding text and reader into a totemic 
figuration of the reading and it flattens or unsettles distinctions between background and foreground, self and environment, objects and experiences of culture and nature, text and world.

In the vast and multiform, intertextual and multispecies worldings conjured in Sérgio Medeiros's work, there are deep resonances with emergent and resistant forms of ecological thinking. His writing exemplifies the proposition that poets and artists, in kinship or affinity with Indigenous cosmovisons and storytellers, remain indispensable "seeing instruments," to borrow ecocritic Joni Adamson's phrase, fostering a perception of and attentiveness to the entanglements of the human with the more-than-human. (Adamson and Monani 3). At a time of profound and intensifying environmental change and anxiety, one that results to great degree out of dualistic forms of seeing and knowing that convert other-than-human entities into mere things, Medeiros's writing draws deeply from animism in a variety of its past and potential manifestations as a vital realm of meaning and as a practice of attentive, imaginative resistance to an objectifying relation with and understanding of the world. In her reflection on an alternative worlding that might/must engage us in response to the Anthropocene, Haraway wonders, "What happens when human exceptionalism and bounded individualism, those old saws of Western philosophy and political economics, become unthinkable? Seriously unthinkable: not available to think with." With ludic inventiveness and ecstatic wonder at the condition of being in the pluriverse, in multispecies and multiepistemic contact zones and entanglements, Medeiros's poetry helps us along in the unthinking of anthropocentrism and helps us to understand decolonization as a vital dimension to that unthinking.

\section{Works Cited}

Adamson, Joni and Salma Monani. "Introduction: Cosmovisions, Ecocriticism, and Indigenous Studies." Ecocriticism and Indigenous Studies: Conversations from Earth to Cosmos, edited by Salma Monani and Joni Adamson, Routledge, 2017, pp. 1-19.

Ajens, Andrés. Poetry after the Invention of America: Don't Light the Flower, translated by Michelle Gil-Montero, Palgrave Macmillan, 2011. 
Avelar, Idelber. "Amerindian Perspectivism and Non-Human Rights." Alter/Nativas vol. 1, 2013, alternativas.osu.edu/en/issues/autumn-2013/ essays/avelar.html. Accessed 21 Jun. 2017.

Ávila, Myriam. "Dêixis e Estranhamento: Caminhos da Nova Poesia Brasileira." Via Atlântica, vol. 11, 2007, pp. 133-44.

Cisneros, Odile. "From the Animal to the Totem: Shifting Perspectives in Contemporary Brazilian Ecopoetics." A poesia na era da internacionalização dos saberes: a produção, a crítica, a tradução e o ensino da poesia no contexto contemporâneo, edited by Charles Perrone, Maria Lúcia Outeiro Fernandes, and Paulo César Andrade da Silva, U Estadual Paulista, 2016, pp. 61-76.

Gennaro, Mara. "Love Stories, or, Multispecies Ethnography, Comparative Literature, and their Entanglements." ACLA State of the Discipline Report, 30 May 2015. stateofthediscipline.acla.org/entry/love-stories-ormultispecies-ethnography-comparative-literature-and-their-entanglements. Accessed 31 May 2017.

Haraway, Donna. "Tentacular Thinking: Anthropocene, Capitalocene, Cthulucene." E-flux, no. 75, Sept. 2016, e-flux.com/journal/ 75/67125/tentacular-thinking-anthropocene-capitalocene-chthulucene/.

Accessed 14 Aug. 2017.

Leão, Rodrigo de Sousa. "Entrevista: Sérgio Medeiros." Germina Literatura, 15 Dec. 2011, www.germinaliteratura.com.br/pcruzadas_sm_nov2006.htm. Accessed 14 Aug. 2017.

Maciel, Maria Esther. "Poéticas do animal." Pensar/escrever o animal: ensaios de zoopoética e biopolítica, edited by Maria Esther Maciel, U Federal de Santa Catarina, 2011, pp. 85-101.

McNee, Malcolm K. The Environmental Imaginary in Brazilian Poetry and Art. Palgrave Macmillan, 2014.

- . "Turns to the Native in Contemporary Brazilian Poetry." A poesia na era da internacionalização dos saberes: a produção, a crítica, a tradução e o ensino da poesia no contexto contemporâneo, edited by Charles Perrone, Maria Lúcia Outeiro Fernandes, and Paulo César Andrade da Silva, U Estadual Paulista, 2016, pp. 45-60.

Medeiros, Sérgio. Alongamento. Ateliê, 2005.

-. O choro da aranha etc. 7 Letras, 2013. 
-. O desencontro dos canibais. Iluminuras, 2013.

—. "O dono dos sonhos adormecido: Sangradouro, anos 80." Folha de São Paulo, 31 Jul. 2012, folha.uol.com.br/fsp/ilustrissima/ il2002201107.htm. Accessed on 31 May 2017.

-. O fim de tarde de uma alma com fome: variações sobre um ou dois temas indígenas. Iluminuras, 2015.

-. Totens. Iluminuras, 2012.

-. Vegetal Sex, translated by Raymond L. Bianchi, U of New Orleans, 2010.

Mentz, Steve. "The Neologismcene.” Arcade, 3 Apr. 2017, arcade.stanford.edu/ blogs/neologismcene. Accessed 31 May 2017.

Ortiz-Robles, Mario. "Comparative Literature and Animal Studies." ACLA State of the Discipline Report, 11 Feb. 2015, stateofthediscipline.acla.org/ entry/comparative-literature-and-animal-studies. Accessed 31 May 2017.

Pádua, José Augusto. "Brazil in the History of the Anthropocene." Brazil in the Anthropocene: Conflicts Between Predatory Development and Environmental Policies, edited by Liz-Rejane Issberner and Philippe Léna, Routledge, 2017, pp. 19-40.

Sundberg, Juanita. "Decolonizing Posthumanist Geographies." Cultural Geographies, vol. 21, no. 1, 2014, pp. 33-47.

Viveiros de Castro, Eduardo. "Cosmological Deixis and Amerindian Perspectivism." Journal of the Royal Anthropological Institute, vol. 4, 1998, pp. 469-88.

-. "Exchanging Perspectives: The Transformation of Objects into Subjects in Amerindian Ontologies." Common Knowledge, vol. 10, no. 3, 2004, pp. 463-84.

- "Some Reflections on the Notion of Species in History and Anthropology." E-misférica, vol. 10, no. 1, Winter 2013, hemisphericinstitute.org/ hemi/en/e-misferica-101/viveiros-de-castro. Accessed 14 Aug. 2017. 